\title{
Meta-analyses comparing the nutritional composition of perennial ryegrass (Lolium perenne) and plantain (Plantago lanceolata) pastures
}

\author{
Elena M. K. MINNEÉ ${ }^{1 *}$, Barbara KUHN-SHERLOCK ${ }^{1}$, Ina J. B. PINXTERHUIS ${ }^{2}$ and David F. CHAPMAN ${ }^{2}$ \\ ${ }^{1}$ DairyNZ, Private Bag 3221, Hamilton 3420, New Zealand \\ ${ }^{2}$ DairyNZ, Canterbury Agriculture and Science Centre, PO Box 85066, Lincoln 7647, New Zealand \\ *Corresponding author: elena.minnee@dairynz.co.nz
}

\begin{abstract}
Studies comparing livestock responses to diets containing plantain with traditional ryegrass/clover diets suggest differences in the nutritional composition between the species might explain some of the variation in results. To explore this theory, a meta-analysis was performed to compare the nutritional composition of plantain and perennial ryegrass pastures, and define key differences between the species. Standardised effect sizes (plantain vs ryegrass pastures), expressed as correlation coefficients $(r)$ with values from -1 to +1 , and treatment means from 34 studies were determined using a weighted random effects model. Pastures containing plantain had lesser herbage dry matter content than ryegrass pastures across all seasons (mean 13.4 vs. $19.4 \%, \mathrm{P}<0.001 ; r<-0.65)$. Structural fibre content was consistently smaller (mean 32.1 vs. $43.4 \% \mathrm{DM}$ ), but non-structural fibre content larger in plantain compared with ryegrass pastures (large effect sizes of $r>0.70$ ). There was no difference in total herbage nitrogen concentration ( $\mathrm{g} / 100 \mathrm{~g} \mathrm{DM} ; r<0.03)$. However, plantain pastures contained less soluble and degradable nitrogen compared with ryegrass pastures $(r<-0.78)$. Herbage digestibility did not differ significantly between pastures $(r=-0.13 ; \mathrm{P}=0.168)$. Generally, the effect of plantain on nutritional composition was consistent across seasons. Experiments and models investigating the effects of pasture mixes on environmental nitrogen losses ought to include detailed nitrogen and carbohydrate fractions data for accurate interpretation and prediction.
\end{abstract}

Keywords: chemical composition, digestibility, fibre, mixed pasture, nitrogen

\section{Introduction}

The forage herb, plantain (Plantago lanceolata) has potential to reduce the environmental impact of intensive livestock systems. Studies of livestock fed perennial ryegrass (Lolium perenne; ryegrass) diets including plantain have consistently demonstrated reduced urine nitrogen $(\mathrm{N})$ concentration, a key determinant of $\mathrm{N}$ leaching risk (Di \& Cameron 2007), at similar or improved levels of production compared to livestock fed diets without plantain (Box et al. 2017;
Minneé et al. 2017; Bryant et al. 2018). It is generally accepted that $\mathrm{N}$ intake influences $\mathrm{N}$ excretion (Kebreab et al. 2001), however, in the studies cited above, $\mathrm{N}$ intake did not wholly explain the variation in urinary $\mathrm{N}$ concentration. It is therefore necessary to understand how plantain differs compositionally to ryegrass, and how consistently these differences are expressed under seasonal variation.

Further, as farmers adopt the use of plantain to reduce $\mathrm{N}$ leaching, methods to account for the plantain in the farm nutrient budgets are required. Direct measurement of nutrient loss is impractical and is generally replaced by simulation modelling. The models should be based on clear understanding of the mechanisms that result in reduced $\mathrm{N}$ leaching and use accurate inputs. While there are several models available that are applicable to pastoral systems (Cichota \& Snow 2009), their predictions will depend on the parameter values used to represent the nutritional composition of ryegrass-based and plantain-based pastures. Confidence in model outputs will be improved if model inputs are based on a standardised set of parameter values drawn from as much available data as possible. To our knowledge, extensive evaluation of the nutritional composition of modern cultivars has not been conducted previously.

The objective of the study reported here was to quantify the nutritional composition of plantain pastures relative to perennial ryegrass pastures with the aim of defining key differences between the species that may explain variation in $\mathrm{N}$ excretion, and to provide robust data for simulation studies involving the use of plantain.

\section{Materials and Methods Data}

A database of key forage quality variables was created from raw data sets obtained from DairyNZ, Massey University, Lincoln University, and published literature. The literature search was performed using the Lincoln University library in October 2018, using the search term 'plantain' with 'chemical composition', 'agronomic evaluation', 'nutritive value' or 'nitrogen concentration'. Inclusion criteria used to refine the data sets in the data base were that the experiment compared 
plantain monoculture or mixed swards containing plantain with perennial ryegrass monoculture or traditional swards containing a mixture of perennial ryegrass and white clover (Trifolium repens). A total of 34 studies were used in the analyses, sixteen from raw data sets and eighteen from the literature (Appendix A). Half of the studies were conducted as agronomic evaluations of the forages, and the other half investigated the effect of forage treatment on livestock production. Only four international studies (from Japan, Sweden and Australia) met the criteria for inclusion. The studies reported chemical composition of the pastures determined by either wet chemistry techniques or estimation by calibrated near infra-red spectroscopy (NIRS).

Studies were grouped into four according to the pasture treatments that were used: (1) Ryegrass monoculture, RyMo; (2) Plantain monoculture, PlMo; (3) Ryegrass in mixed sward, RyWc; (4) Plantain in mixed sward, PIX.

\section{Calculations and statistical analyses}

Due to the range of techniques employed across the studies to quantify the concentration of readily fermentable carbohydrates, an estimation of nonstructural carbohydrate (NSC) was made where possible using Equation $1^{1}$ :

\section{NSC $=100-($ Crude protein + Neutral detergent Fibre + Ash + Lipid)}

\section{[Equation 1]}

To quantify the size of the effect between ryegrass and plantain pastures, the correlation coefficient $r$ was calculated as per Field (2005). Effect size was calculated for each study, year the study was conducted, and season in which the data were collected. Seasons were defined as per the DairyNZ Forage Value Index (FVI): winter, early spring, late spring, summer, and autumn (Chapman et al. 2017). For the raw data sets, a one-way analysis of variance (ANOVA; SAS Institute Inc., NC, USA) was performed to evaluate the effect of pasture treatment. The resulting F-ratio and residual degrees of freedom $\left(d f_{R}\right)$ were used to calculate $r$ according to Equation 2.

$$
r=\sqrt{\frac{F(1,-)}{F(1,-)+d f_{R}}}
$$

\section{[Equation 2]}

For published data, unless the standard error of the mean (SEM) was reported, it was calculated using reported standard deviation (SD), standard error of the difference

1 Equivalent to Equation 47 in Tylutki et al. (2008).
(SED), least significant difference (LSD) or P-values. T-value and residual $d f$ were calculated based on difference between ryegrass and plantain pastures, SEM, and sample size, and used to derive $r$ by Equation 3:

$$
r=\sqrt{\frac{t^{2}}{t^{2}+d f}}
$$

[Equation 3]

Where the result for plantain pastures was less than the ryegrass pastures $r$ is multiplied by -1 to obtain directional effects.

A meta analysis of the effect sizes was conducted to generate weighted effect sizes (LSM) using a random effects model (Proc Mixed, SAS/STAT 14.3) with a) intercept only or b) treatment as fixed effect, study as a random effect and $n$ as weighting variable.

Means from the raw data sets and literature data were used in a meta-analysis to generate weighted means (LSM) for the original variables using the same random effects model with pasture treatment, season, and their interaction as fixed effects, study as a random effect, and $n$ as weighting variable. Mean effect size and treatment least square means, with $95 \%$ confidence interval and associated P-value are reported.

The strength of the relationship is defined as strong when $r \geq 0.7$, moderate for $r=0.50-0.69$, weak for $r=0.30-0.49$, and very weak when $r<0.30$ (Schober et al. 2018).

\section{Results and Discussion Herbage dry matter content}

Herbage dry matter (DM) content was significantly less in plantain monocultures or mixtures containing plantain than in ryegrass pastures (LSM 13.4 vs. 19.4\%; $\mathrm{P}<0.01$; Table 1 ). The size of the effect was strongly negative and consistent across all pasture comparisons $(r \geq-0.68, \mathrm{P}<0.001)$. Monocultures of plantain were on average $30 \%$ less in DM than ryegrass monocultures, and the effect was consistent across seasons (P pasture $\times$ season $=0.665$ ).

Lower urinary $\mathrm{N}$ concentration from livestock consuming plantain containing diets, compared to livestock consuming ryegrass diets, has been reported in several studies (Minneé et al. 2017; Box et al. 2017; Bryant et al. 2017; Bryant et al. 2018). One possible mechanism for this difference is the large water content (low DM content) of herbage containing plantain (O'Connell et al. 2016). The increased consumption of water from such a diet induces diuresis, which results in diluted urine (Atherton et al. 1968). In a recent study, it was demonstrated that cattle fed $45 \%$ of the daily DM intake in the form of plantain consumed $\sim 60 \%$ more water in the feed than cattle fed diets without plantain (Minnée et al. unpublished data). 


\section{Herbage nitrogen and nitrogen fractions}

Generally, the herbage total $\mathrm{N}$ concentration of herbage of monocultures of plantain and ryegrass was similar (mean $3.1 \mathrm{~g} / 100 \mathrm{~g} \mathrm{DM} ; r=0.03 ; \mathrm{P}>0.05$ ) (Table 2). Differences in pasture total $\mathrm{N}$ concentration appear influenced by the presence of other species, likely to be sown legumes, as the analyses showed that monoculture pastures of ryegrass or plantain had less total $\mathrm{N}$ than traditional ryegrass/white clover pastures or plantain in diverse swards with legumes. Legumes, such as white clover and lucerne (Medicago sativa) are common in diverse mixtures and typically have total $\mathrm{N}$ contents $4.3 \mathrm{~g} / 100 \mathrm{~g} \mathrm{DM}$ (Martin et al. 2017), thus their presence in a sward will elevate total pasture $\mathrm{N}$ content.

Table 1 Correlation coefficient ( $r$ ) of the weighted effect size for effects of pasture type on herbage dry matter content, with least squares means with upper and lower confidence limits for pasture type.

\begin{tabular}{|c|c|c|c|c|c|c|c|c|c|c|c|c|}
\hline \multirow[b]{2}{*}{ Comparison } & \multirow[b]{2}{*}{ Season } & \multicolumn{4}{|c|}{$r$ (weighted effect) } & \multicolumn{3}{|c|}{ Perennial ryegrass } & \multicolumn{4}{|c|}{ Plantain } \\
\hline & & LSM & SE & df & $P$ value & LSM & Lower & Upper & LSM & Lower & Upper & $P$ value \\
\hline RyMo vs PIMo & All & -0.79 & 0.021 & 31 & $<0.001$ & 21.1 & 19.2 & 23.0 & 14.8 & 12.9 & 16.7 & $<0.001$ \\
\hline RyMo vs PIX & All & -0.80 & 0.048 & 8 & $<0.001$ & 20.6 & 17.0 & 24.2 & 13.3 & 9.7 & 16.9 & 0.0016 \\
\hline RyWc vs PIMo & All & -0.83 & 0.030 & 23 & $<0.001$ & 17.4 & 15.4 & 19.5 & 11.8 & 9.8 & 13.9 & $<0.001$ \\
\hline RyWc vs PIX & All & -0.68 & 0.057 & 36 & $<0.001$ & 18.4 & 17.0 & 19.8 & 13.7 & 12.3 & 15.1 & $<0.001$ \\
\hline \multicolumn{13}{|l|}{ Seasonal effect } \\
\hline RyMo vs PIMo & Winter & -0.87 & 0.090 & 16 & $<0.001$ & 18.3 & 12.9 & 23.7 & 12.3 & 6.9 & 17.7 & 0.1073 \\
\hline RyMo vs PIMo & Early Spring & -0.78 & 0.079 & 16 & $<0.001$ & 25.5 & 20.8 & 30.3 & 19.4 & 14.6 & 24.2 & 0.0592 \\
\hline RyMo vs PIMo & Late Spring & -0.78 & 0.034 & 16 & $<0.001$ & 20.6 & 18.4 & 22.9 & 14.3 & 12.1 & 16.6 & $<0.001$ \\
\hline RyMo vs PIMo & Summer & -0.82 & 0.032 & 16 & $<0.001$ & 22.3 & 20.2 & 24.4 & 14.3 & 12.2 & 16.4 & $<0.001$ \\
\hline RyMo vs PIMo & Autumn & -0.68 & 0.037 & 16 & $<0.001$ & 18.6 & 16.2 & 21.0 & 13.5 & 11.1 & 15.8 & 0.0009 \\
\hline
\end{tabular}

LSM, Least squares means; SE, standard error of the mean; df, residual degrees of freedom (= number of data points contributing to the analyses minus 2); Lower, lower $95 \%$ confidence limit; Upper, upper $95 \%$ confidence limit.

Table 2 Correlation coefficient $(r)$ of the weighted effect size for effects of pasture type on herbage nitrogen ( $N$ ) content, and proportions of soluble and degradable $\mathrm{N}$ within total $\mathrm{N}$, with least squares means with upper and lower confidence limits for pasture type.

\begin{tabular}{|c|c|c|c|c|c|c|c|c|c|c|c|c|}
\hline \multirow[b]{2}{*}{ Comparison } & \multirow[b]{2}{*}{ Season } & \multicolumn{4}{|c|}{$r$ (weighted effect) } & \multicolumn{3}{|c|}{ Perennial ryegrass } & \multicolumn{4}{|c|}{ Plantain } \\
\hline & & LSM & SE & df & $P$ value & LSM & $\begin{array}{c}\text { Lower } \\
1 / 4\end{array}$ & $\begin{array}{c}\text { Upper } \\
1 / 4\end{array}$ & LSM & $\begin{array}{c}\text { Lower } \\
1 / 4\end{array}$ & $\begin{array}{c}\text { Upper } \\
1 / 4\end{array}$ & $P$ value \\
\hline \multicolumn{13}{|c|}{ Total Nitrogen (\% dry matter) } \\
\hline RyMo vs PIMo & All & 0.03 & 0.070 & 39 & 0.6768 & 3.1 & 2.7 & 3.4 & 3.2 & 2.8 & 3.5 & 0.5207 \\
\hline RyMo vs PIX & All & 0.24 & 0.100 & 11 & 0.0381 & 3.0 & 2.6 & 3.4 & 3.4 & 3.0 & 3.8 & 0.0979 \\
\hline RyWc vs PIMo & All & -0.47 & 0.078 & 32 & $<0.001$ & 3.4 & 3.1 & 3.6 & 3.1 & 2.8 & 3.3 & 0.0050 \\
\hline RyWc vs PIX & All & 0.09 & 0.080 & 43 & 0.2871 & 3.1 & 2.8 & 3.4 & 3.2 & 3.0 & 3.5 & 0.0707 \\
\hline \multicolumn{13}{|c|}{ Soluble $N$ (\% of total $N$ content) } \\
\hline RyMo vs PIMo & All & -0.97 & 0.012 & 3 & $<0.001$ & 38.4 & 31.8 & 45.0 & 12.0 & 5.3 & 18.6 & 0.0012 \\
\hline RyMo vs PIX & All & -0.81 & 0.105 & 3 & 0.0046 & 38.4 & 27.3 & 44.3 & 27.3 & 21.4 & 33.3 & 0.0171 \\
\hline RyWc vs PIMo & All & -0.97 & 0.014 & 3 & $<0.001$ & 38.4 & 29.3 & 47.2 & 12.0 & 2.9 & 21.0 & 0.0015 \\
\hline RyWc vs PIX & All & -0.78 & 0.127 & 3 & 0.0088 & 38.4 & 29.8 & 46.9 & 27.4 & 18.8 & 36.0 & 0.0363 \\
\hline \multicolumn{13}{|c|}{ Degradable $N$ (\% of total $N$ content) } \\
\hline RyMo vs PIMo & All & -0.97 & 0.012 & 3 & $<0.001$ & 69.2 & 65.9 & 72.5 & 56.0 & 52.7 & 59.3 & 0.0011 \\
\hline RyMo vs PIX & All & -0.81 & 0.104 & 3 & 0.0044 & 69.2 & 66.3 & 72.2 & 63.7 & 60.7 & 66.6 & 0.0167 \\
\hline RyWc vs PIMo & All & -0.97 & 0.014 & 3 & $<0.001$ & 69.2 & 64.7 & 73.7 & 56.0 & 51.5 & 60.5 & 0.0015 \\
\hline RyWc vs PIX & All & -0.78 & 0.127 & 3 & 0.0089 & 69.2 & 64.9 & 73.5 & 63.7 & 59.4 & 68.01 & 0.0363 \\
\hline
\end{tabular}


While total $\mathrm{N}$ content for plantain and ryegrass monocultures was similar, there were strong negative effect sizes for the proportions of total $\mathrm{N}$ that are soluble and degradable $(r=-0.97, \quad \mathrm{P}<0.001$; Table $2)$. Soluble $N$ content in plantain and ryegrass monocultures was $\sim 12$ vs $38 \%$ of total $\mathrm{N}$, respectively $(\mathrm{P}<0.001)$, and degradable $\mathrm{N}$ content in plantain and ryegrass monocultures $56 \%$ and $69 \%$ of total $\mathrm{N}$, respectively $(\mathrm{P}=0.001)$. Reductions in the amount of soluble and degradable $\mathrm{N}$ may explain reduced rumen ammonia concentrations of livestock fed plantain compared to ryegrass (Minneé et al. 2017, Swainson \& Hoskin 2006). It might also explain observed differences in $\mathrm{N}$ partitioning (Totty et al. 2013), since increased undegradable $\mathrm{N}$ can result in more $\mathrm{N}$ being partitioned to faeces (Bryant et al. 2012) which is then less susceptible to leaching and conversion to nitrous oxide (a potent greenhouse gas) (Lockyer \& Whitehead 1990).

\section{Carbohydrate}

Plantain contained less structural carbohydrate (SC) (measured as neutral detergent fibre, NDF) than ryegrass (LSM 29 and $43 \mathrm{~g} / 100 \mathrm{~g}$ DM from PIMo and RyMo pastures respectively, $\mathrm{P}<0.001$, Table 3 ). Therefore, the presence of plantain in a pasture with ryegrass will influence the SC content of the whole pasture. An interaction between pasture type and season was observed for NDF content, where the effect size was smaller in winter $(r=-0.74)$ compared with other seasons $(r>-0.80)$, which may reflect a vegetative state with lesser dead matter content of ryegrass in winter compared with other seasons.

Non-structural carbohydrates (NSC) are the primary source of energy for rumen microbes (Kebreab et al. 2009). Plantain was shown to have consistently greater NSC content than ryegrass (Table
$3)$, with a trend for greater effect size and difference in autumn ( $r=0.91, \mathrm{P}<0.001 ; 30$ vs $16 \mathrm{~g} / 100 \mathrm{~g} \mathrm{DM}$ from PIMo and RyMo respectively, $\mathrm{P}<0.001$ ). The NSC: $N$ ratio of the diet has a substantial effect on $\mathrm{N}$ partitioning in ruminants, where the proportion of dietary $\mathrm{N}$ eaten partitioned to urine declines as NSC: $\mathrm{N}$ increases (Edwards et al. 2007; Belanche et al. 2013; Moorby 2014). Given that the N content of herbage from plantain pastures was similar to, or less than, herbage from ryegrass pastures (Table 2), the NSC: $\mathrm{N}$ ratio in plantain should consistently favour partitioning of dietary $\mathrm{N}$ from urine to other sinks, and may explain differences in urinary $\mathrm{N}$ excretion and production responses observed when livestock are fed diets containing plantain (Box et al. 2017; Hutton et al. 2011; Moorhead et al. 2002).

\section{Ash and lipid content}

Mineral (ash) content was greater in pastures containing plantain ( $r>0.6$ for all pasture comparisons) compared with ryegrass. In monoculture, ash content was 12.8 and $10.2 \mathrm{~g} / 100 \mathrm{~g}$ DM for PIMo and RyMo respectively ( $\mathrm{P}<0.001)$, and the effect was consistent across seasons. A small ( $r=-0.19)$ but significant effect of reduced lipid content in plantain compared to ryegrass monocultures was observed. Greater effects were observed comparing plantain pastures with RyWc indicating legumes in pastures elevate herbage lipid content $(r=-0.85 ; 2.5 \mathrm{vs}$. $3.5 \mathrm{~g} / 100 \mathrm{~g}$ for PIMo and RyWc respectively).

\section{Herbage digestibility}

The digestibility of plantain and ryegrass monoculture pastures was similar ( $r=-0.13$; LSM 77.8 vs $77.2 \%$ for RyMo and PIMo respectively, $\mathrm{P}=0.339$ ). However, there was a trend $(\mathrm{P}=0.053)$ for an interaction between pasture and season where digestibility was reduced to $74 \%$ in plantain in late spring and summer compared

Table 3

Correlation coefficient ( $r$ ) of the weighted effect size for effects of pasture type on herbage neutral fibre, acid detergent fibre and non-structural carbohydrate content, with least squares means (\% of dry matter) with upper and lower confidence limits for pasture type.

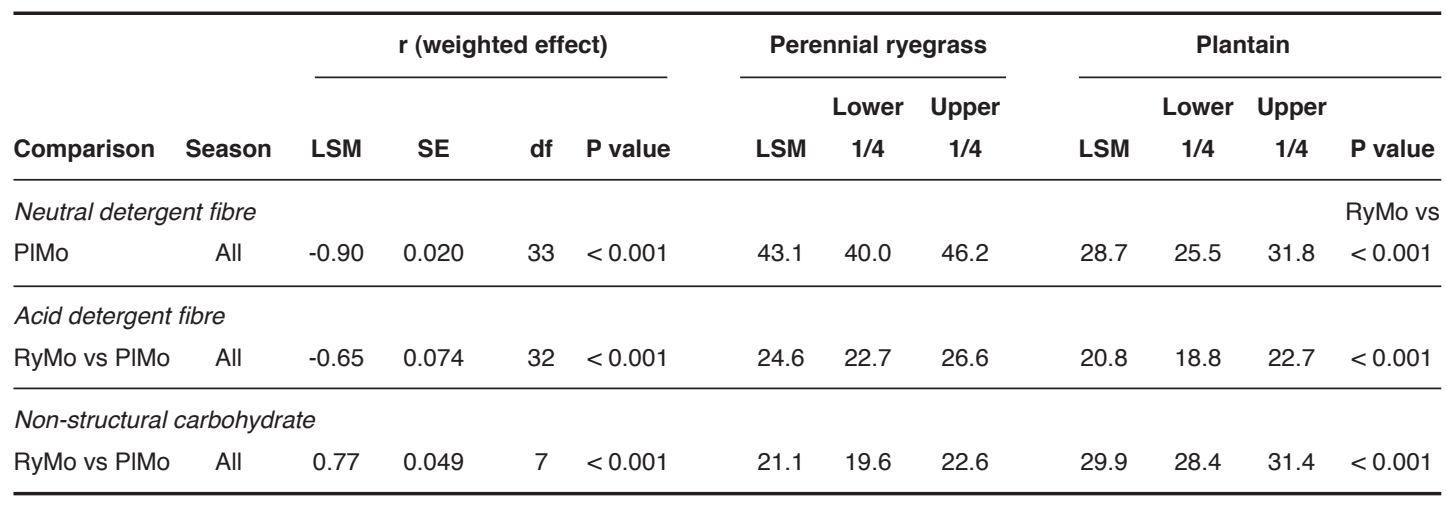


to $78 \%$ in ryegrass. This may reflect the reproductive stage of plantain at that time of year when the plant flowers profusely (Lee et al. 2015), or elevation in concentration of secondary compounds in plantain herbage (aucubin and acteoside) in these seasons (Box et al. 2019).

\section{Conclusions}

Perennial ryegrass and plantain did not differ in two commonly measured, and important, attributes for livestock nitrogen metabolism: total herbage nitrogen content and herbage digestibility. However, there were clear and consistent differences in DM and carbohydrate content, the partitioning of total herbage $\mathrm{N}$ between degradable and non-degradable forms, indicating that this may be more important than total $\mathrm{N}$ for influencing urinary $\mathrm{N}$ excretion.

This study highlighted compositional differences between ryegrass and plantain that are not routinely measured. Considering the likely importance of the alternative indicators for $\mathrm{N}$ partitioning and urine $\mathrm{N}$ excretion, we suggest future field research or simulation modelling addressing the effect of forage species on $\mathrm{N}$ leaching risk in grazing livestock production systems will need to include these attributes.

\section{ACKNOWLEDGEMENTS}

The authors wish to thank New Zealand dairy farmers through DairyNZ Inc. for funding this study, and data from previous research programs; and the researchers and institutions who generously supplied raw data for inclusion, namely R. Bryant, S. Navarrete and L. Cranston. Several data sets were obtained, and compilation of the database was conducted with support, from the Forages for Reduced Nitrate Leaching (FRNL) programme of research. The FRNL programme has principal funding from the New Zealand Ministry of Business, Innovation and Employment. The programme is a partnership between DairyNZ, AgResearch, Plant $\&$ Food Research, Lincoln University, The Foundation for Arable Research and Manaaki Whenua - Landcare Research.

\section{REFERENCES}

Atherton JC, Hai MA, Thomas S. 1968. Effects of water diuresis and osmotic (mannitol) diuresis on urinary solute excretion by the conscious rat. The Journal of Physiology 197: 395-410.

Belanche A, Lee MRF, Moorby JM, Newbold CJ. 2013. Comparison of ryegrass and red clover on the fermentation pattern, microbial community and efficiency of diet utilisation in the rumen simulation technique (Rusitec). Animal Production Science 53: 1052-1064.

Box LA, Edwards GR, Bryant RH. 2017. Milk production and urinary nitrogen excretion of dairy cows grazing plantain in early and late lactation. New Zealand Journal of Agricultural Research 60: 470-482.

Box, LA, Edwards, GR, Bryant, RH. 2019. Seasonal and diurnal changes in aucubin, catalpol and acteoside concentration of plantain herbage grown at high and low $\mathrm{N}$ fertiliser inputs. New Zealand Journal of Agricultural Research 62: 343-353.

Bryant RH, Gregorini P, Edwards GR. 2012. Effects of $\mathrm{N}$ fertilisation, leaf appearance and time of day on $\mathrm{N}$ fractionation and chemical composition of Lolium perenne cultivars in spring. Animal Feed Science and Technology 173: 210-219.

Bryant RH, Miller ME, Greenwood SL, Edwards GR. 2017. Milk yield and nitrogen excretion of dairy cows grazing binary and multispecies pastures. Grass and Forage Science 72: 806-817.

Bryant RH, Welten BG, Costall D, Shorten PR, Edwards GR. 2018. Milk yield and urinary-nitrogen excretion of dairy cows grazing forb pasture mixtures designed to reduce nitrogen leaching. Livestock Science 209: 46-53.

Chapman DF, Bryant JR, Olayemi ME, Edwards GR, Thorrold BS, McMillan WH, Kerr GA, Judson G, Cookson T, Moorhead A, Norriss M. 2017. An economically based evaluation index for perennial and short-term ryegrasses in New Zealand dairy farm systems. Grass and Forage Science 72: 1-21.

Cichota R, Snow VO. 2009. Estimating nurient loss to waterways - an overview of models of relevance to New Zealand pastoral farms. New Zealand Journal of Agricultural Research 52: 239-260.

Di H, Cameron KC. 2007. Nitrate leaching losses and pasture yields as affected by different rates of animal urine nitrogen returns and application of a nitrification inhibitor - a lysimeter study. Nutrient Cycling in Agroecosystems 79: 281-290.

Edwards GR, Parsons AJ, Rasmussen S, Bryant RH. 2007. High sugar ryegrasses for livestock systems in New Zealand. Proceedings of the New Zealand Grassland Association 69: 161-171.

Field AP. 2005. Meta-analysis. In: Miles J \& Gilbert P Eds. A handbook of research methods in clinical and health psychology. Oxford Univeristy Press, Oxford, United Kingdom. pp. 295-308.

Hutton PG, Kenyon PR, Bedi MK, Kemp PD, Stafford, KJ, West DM, Morris ST. 2011. A herb and legume sward mix increased ewe milk production and ewe and lamb live weight gain to weaning compared to a ryegrass dominant sward. Animal Feed Science and Technology 164: 1-7.

Kebreab E, Dijkstra J, Bannink A, France J. 2009. Recent advances in modelling nutrient utilization in ruminants. Journal of Animal Science 87: E111-E122. 
Kebreab E, France J, Beever DE, Castillo AR. 2001. Nitrogen pollution by dairy cows and its mitigation by dietary manipulation. Nutrient Cycling in Agroecosystems 60: 275-285.

Lee JM, Hemmingson NR, Minneé EMK, Clark CEF. 2015. Management strategies for chicory (Cichorium intybus) and plantain (Plantago lanceolata): impact on dry matter yield, nutritive characteristics and plant density. Crop and Pasture Science 66: 168-183.

Lockyer DR, Whitehead DC. 1990. Volatilization of ammonia from cattle urine applied to grassland. Soil Biology and Biochemistry 22: 1137-1142.

Martin K, Edwards G, Bryant R, Hodge M, Moir J, Chapman D, Cameron K. 2017. Herbage dry-matter yield and nitrogen concentration of grass, legume and herb species grown at different nitrogen-fertiliser rates under irrigation. Animal Production Science 57: 1283-1288.

Minneé EMK, Waghorn GC, Lee JM, Clark CEF. 2017. Including chicory or plantain in a perennial ryegrass/white clover-based diet of dairy cattle in late lactation: Feed intake, milk production and rumen digestion. Animal Feed Science and Technology 227: 52-61.

Moorby JM. 2014. Relationship between the composition of fresh grass-based diets and the excretion of dietary nitrogen from dairy cows. In: Hopkins A, Collins RP, Fraser MD, King VR, Lloyd DC, Moorby JM \& Robson PRH Eds. EGF at 50: The Future of European Grasslands. IBERS, Aberstwyth University, Aberstwyth, Wales, pp. 686-689.

Moorhead AJE, Judson HG, Stewart AV. 2002. Liveweight gain of lambs grazing 'Ceres Tonic' plantain (Plantago lanceolata) or perennial ryegrass (Lolium perenne). Proceedings of the New Zealand Society of Animal Production 62: 171-173.

O'Connell CA, Judson HG, Barrella GK. 2016. Sustained diuretic effect of plantain when ingested by sheep. New Zealand Society of Animal Production 76: 24-27.

Schober P, Boer C, Schwarte LA. 2018. Correlation coefficients: appropriate use and interpretation. Anesthesia \& Analgesia 126: 1763-1768.

Swainson NM, Hoskin SO. 2006. Apparent digestibility and rumen fermentation of fresh plantain (Plantago lanceolata cv Ceres Tonic) and perennial ryegrass (Lolium perenne cv Nui)-based pasture fed to red deer (Cervus elaphus). Proceedings of the New Zealand Society of Animal Production 66: 64-69.

Totty VK, Greenwood SL, Bryant RH, Edwards GR. 2013. Nitrogen partitioning and milk production of dairy cows grazing simple and diverse pastures. Journal of Dairy Science 96: 141-149.

Tylutki TP, Fox DG, Durbal VM, Tedeschi LO, Russell JB, Van Amburgh ME, Overton TR, Chase LE, Pell
AN. 2008. Cornell Net Carbohydrate and Protein System: A model for precision feeding of dairy cattle. Animal Feed Science and Technology 143: 174-202.

\section{Appendix A}

Literature included in the analyses

Al-Mamum M, Daisuke ABE, Kofujita H, Tamura Y, Sano H. 2008. Comparison of the bioactive components of the ecotypes and cultivars of plantain (Plantago lanceloata L.) herbs. Animal Science Journal 79: 83-88.

Barry R. 2015. Nitrogen use efficiency and feed conversion efficiency of lactating dairy cows grazing simple and diverse pastures. Honours Dissertation. Lincoln University.

Bryant RH, Miller ME, Greenwood SL, Edwards GR. 2017. Milk yield and nitrogen excretion of dairy cows grazing binary and multispecies pastures. Grass and Forage Science 72: 806-817.

Bryant RH, Welten BG, Costall D, Shorten PR, Edwards GR. 2018. Milk yield and urinary-nitrogen excretion of dairy cows grazing forb pasture mixtures designed to reduce nitrogen leaching. Livestock Science 209: 46-53.

Cheng L, McCormick J, Hussein AN, Logan C, Pacheco D, Hodge MC, Edwards GR. 2017. Live weight gain, urinary nitrogen excretion and urination behaviour of dairy heifers grazing pasture, chicory and plantain. The Journal of Agricultural Science 155: 669-678.

Cheng L, Judson HG, Bryant RH, Mowat H, Guinot L, Hague H, Taylor S, Edwards, GR. 2017. The effects of feeding cut plantain and perennial ryegrass-white clover pasture on dairy heifer feed and water intake, apparent nutrient digestibility, and nitrogen excretion in urine. Animal Feed Science and Technology 229: 43-46.

Cranston LM, Kenyon PR, Morris ST, Lopez-Villalobos N, Kemp PD. 2015. Effect of post-grazing height on the productivity, population and morphology of a herb and legume mix. New Zealand Journal of Agricultural Research 58: 397-411.

Edwards GR, Bryant RH, Smith N, Hague H, Taylor S, Ferris A, Farrell L. 2015. Milk production and urination behaviour of dairy cows grazing diverse and simple pastures. Proceedings of the New Zealand Society of Animal Production 75: 79-83.

Fulkerson WJ, Horadagoda A, Neal JS, Barchia I, Nandra KS. 2008. Nutritive value of forage species grown in the warm temperate climate of Australia for dairy cows: Herbs and grain crops. Livestock Science 114: 75-83.

Harrington KC, Thatcher A, Kemp PD. 2006. Mineral composition and nutritive value of some common pasture weeds. New Zealand Plant Protection 59: 261-265. 
Lindstrom BEM, Franklow-Lindberg BE, Dahlin AS, Wivstad M, Watson CA. 2012. Micronutrient concentrations in common and novel forage species and varieties grown on two contrasting soils. Grass and Forage Science 1-10.

Nkomboni D. 2017. Effect of plantain (Plantago lanceolata L.) proportion in the diet on nitrogen use, milk production and behaviour of lactating dairy cows. Masters Thesis. Lincoln University.

Pembleton KG, Hills JL, Freeman MJ, McLaren DK, French M, Rawnsley RP. 2016. More milk from forage: Milk production, blood metabolites, and forage intake of dairy cows grazing pasture mixtures and spatially adjacent monocultures. Journal of Dairy Science 99: 3512-3528.
Somasiri SC, Kenyon PR, Morel PCH, Kemp PD, Morris ST. 2015. Herb-clover mixes increase lamb live weight gain and carcass weight in the autumn period. New Zealand Journal of Agricultural Research 58: 1-13.

Swainson NM, Hoskin SO. 2006. Apparent digestibility and rumen fermentation of fresh plantain (Plantago lanceolata cv Ceres Tonic) and perennial ryegrass (Lolium perenne cv Nui) -based pasture fed to red deer (Cervus elaphus). Proceedings of the New Zealand Society of Animal Production 66: 64-69.

Totty VK, Greenwood SL, Bryant RH, Edwards GR. 2013. Nitrogen partitioning and milk production of dairy cows grazing simple and diverse pastures. Journal of Dairy Science 96: 141-149. 
